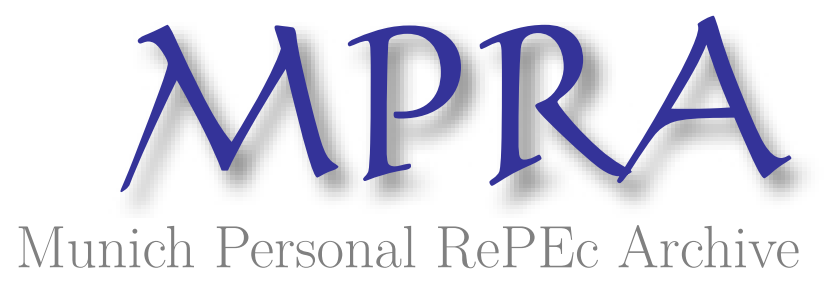

\title{
FOREIGN DIRECT INVESTMENT AND ECONOMIC GROWTH: SOME EVIDENCE FROM ACROSS THE WORLD
}

Halicioglu, Anita and Halicioglu, Ferda

2006

Online at https://mpra.ub.uni-muenchen.de/3563/

MPRA Paper No. 3563, posted 15 Jun 2007 UTC 


\title{
FOREIGN DIRECT INVESTMENT AND ECONOMIC GROWTH: SOME EVIDENCE FROM ACROSS THE WORLD
}

\author{
Anita GHATAK and Ferda HALICIOGLU* \\ Department of Economics, School of Business, the University of Greenwich \\ Park Row, Maritime, Greenwich, London SE10 9LS, UK \\ Department of Economics, Yeditepe University, Istanbul, Turkey \\ E-mail: A.Ghatak@gre.ac.uk E-mail: fhalicioglu@yeditepe.edu.tr
}

\begin{abstract}
This study is concerned about foreign direct investment (FDI) and economic growth across the world for the period of 1991-2001. This article produces fresh empirical evidence on the relation between FDI and economic growth obtained from single-equation and simultaneous equation estimates for 140 countries using macro economic variables. The results indicate that a positive and statistically significant estimate of coefficient of FDI is obtained from single equation ordinary least squares method for real per-capita GDP regressions in all but one case. There exists a positive and statistically significant relation between the real per-capita GDP and FDI in the case of many countries but correlation coefficient between exportsGDP ratio and percentage FDI is found to be insignificant. Country risk rating and the telecommunications variables are significant in all the relevant regressions and correlation estimates.
\end{abstract}

Keywords: Foreign direct investment; multinational corporations; composite risk rating; instrumental variable method; omitted variable method; simultaneous equation method.

JEL: F15, F21, C32

\footnotetext{
* Corresponding author.
} 


\section{Introduction}

Development economists generally believe in positive spill over effects of foreign direct investment (FDI) on economic growth and development in the less developed countries (LDCs). Such effects are normally believed to be increases in employment, increases in productivity, increases in exports, and, of course, possible transfer of technology. See for example, De Mello (1997), Bruno and Easterly (1998), Lim (2001), and Slywester (2005) for recent empirical evidences and techniques are employed in these studies.

It is of concern among many policy makers that the recent downturn in global investment inflows in the early part of the twenty first century can be very damaging for long-term economic development of many LDCs. United Nations (UN) 2003 FDI data report a fall in FDI inflows from \$1.4 trillion in 2000 to \$650 billion in 2002. According to the UN report, it is "rule-making at the international level" which is standing more in the way of LDCs benefiting from the positive effects of FDI (UN, 2003). National Government policies are also important as they can give either an incentive or a disincentive to FDI. For example, tax exemption, grants and subsidised loans, special credit privileges, permission to profit remittance, and such like, would give incentive to FDI; whereas restrictions on foreign ownership, profit remittances, size and location could have a negative effect. In some countries, foreign firms are required to use host country's resources and export a part of their output and such policies of the host government can act as disincentive to FDI; likewise, various bureaucratic delays in processing of applications from foreign firms and in authorising and granting licenses to investment projects would not encourage investment from foreign companies.

As far as the traditional approach is concerned, the linkages between the FDI flows and economic growth are based on either market imperfection approach (MIA) or industrial organisation approach (IOA). The MIA is based on the assumption that benefits from FDI will be available if there are market imperfections see for example Dunning (1993). The IOA holds that FDI also involves transfer of resources other than capital, for instance, technology, marketing skills, management, and such like; and an important determinant of FDI is the expected rate of return on these rather than capital as such (Kindleberger, 1969). Foreign firms may not always choose such technologies which would benefit the host country but may choose capital-intensive technologies in the LDCs because such technologies combined with organisational, financial and marketing factors can give the MNCs a unique advantage over the local firms as discussed in Lall (1980). The other argument concerns the loss of benefits of competition due to the oligopol or monopolistic structure based on product specialisation and not on comparative advantage of countries see for example, Caves, (1971, 1974), Saunders (1982), Gupta (1983), and Kumar (1987).

The research on economic growth has been growing from the mid 1990s which is based on endogenous technological progress as a main driving force of growth (Romer, 1990 and Grossman and Helpman, 1991). To this end, some countries are able to innovate and develop their own technology but other may benefit from the diffusion of technology that is produced somewhere else. FDI is considered to be one of the main channels of this process in the case of the second group countries as discussed in Borensztein, et al. (1998). 
The empirical evidence on FDI and economic growth has also been expanding in the lights of the new economic growth theory and traditional FDI theories. There exist several empirical evidences based on individual and cross countries such as De Gregorio (1992) Balasubramanyam et al (1996), Zhang (2001), Biswas, (2002), and Bengoa and Sanchez-Robles (2003) however; results in this regard appear to be inconclusive due to the techniques and time span of data.

In this paper, our approach is aggregative; we use the cross-country data published in the World Investment Report (UN, 2003) to assess the extent of some of the positive effects of inward FDI in stock on a large number of key macro variables crucial for economic growth and development by applying OLS and IVM techniques.

To this end, in the next section we outline theory and methodology. Section 3 describes the data and variables. Section 4 is devoted to the interpretation of regression estimates. Section 5 provides conclusion of this paper. Finally, the last section presents the summary tables of OLS and IVM techniques.

\section{Theory and Methodology}

The main problem that we face in modelling the "theories" of FDI is that of circularity or feedback in the relation between FDI and economic growth. It is indicated in the above discussion as well as in some of the existing literature, that one of the determinants of FDI itself can be the rate of growth in the host country as this would also influence the expected rate of return on capital and other resources, not just the market size (Root and Ahmet, 1979); there is a view that differences in the FDI can be explained by differential rates of return on capital investment; capital moves from where it is plenty and cheap to where it is scarce and more expensive. A positive relationship was found between flow of US investment and rate of return on capital in Europe in the 1950s; although US FDI in Europe continued despite the domestic rates of return being higher than those in Europe in the 1960s. Applied studies also found positive influence of rate of return on FDI in Latin America, Argentina, Brazil, Chile, India, Indonesia, Mexico and the Philippines, Turkey but only at the regional level and not for individual countries as a whole (Stevens, 1969; Rueber et. al, 1973; Hufbauer, 1975, Blostrom, 1986, De Gregorio, 1992, Halicioglu, 2001). However, the results from existing empirical studies are often inconclusive because of limitations of the data, the methodology used, and such like.

In this paper, our interest is to assess, globally, the contribution of FDI to economic growth and to real per-capita GDP in the host country in a sample of one hundred and forty countries for the period 1991-2001. We have decided to apply

(1) single-equation method along with auxiliary regressions and linear correlation and

(2) apply simultaneous equation method using country risk rating as the instrument to account for possible feedback and two-way dependence. The reason is not for solely relying on simultaneous equation method (SEM) concerns the arbitrary nature of classifying variables into endogenous and exogenous categories (Liu, 1960; Sims, 1972) and assuming "economic theory" before proof. This objection to applying SEM is more serious in time-series data and a remedy is offered in the method of vector autoregression models (VAR) which classifies all variables as endogenous. In our cross-country data, we try to assess causality by regression and strength of relationship by linear correlation before assuming endogeneity of the explanatory variable in question, namely, FDI. Therefore, along with SEM estimates, we also estimate a number of auxiliary regressions, linear correlation and test significance of 
the latter for the purpose of establishing first whether our theoretical assumption of simultaneity in the relation or the endogeneity of explanatory variables exists in the data. Various auxiliary regressions estimated for this purpose are given in the set of equations (4i) to (4xi).

We consider the effects of FDI inflows on some key variables for the developing and the developed countries together as published in the UN (2003). The choice of variables is according to their strategic and macroeconomic importance and prompted by data availability. The key dependent variables in question are real per-capita GDP, $\mathrm{Y}$, the growth of real per-capita GDP, g, and the scores of these variables. While we want to assess the impact of FDI, on economic growth, we also need to include other independent variables which are typically expected to influence economic growth, according to common logic or already established theories. This will reduce or eliminate specification error in respective equations. For instance, export-led growth is a much discussed hypothesis. Therefore, in assessing impact of $F$ on economic growth, and on real per-capita GDP, we consider the following two multiple regressions as the main equations of our interest:

$$
\begin{aligned}
& g=a+b_{1} F+b_{2} X+b_{3} T+u \\
& Y=a+b_{1} F+b_{2} X+b_{3} T+u
\end{aligned}
$$

Our simultaneous-equation model for $g$ can be written as

$g=a+b_{1} F+b_{2} X+b_{3} T+u_{1}$
$F=a+c_{1} g+c_{2} T+c_{3} C R+u_{2}$

and the simultaneous equation model for $\mathrm{Y}$ can be written as:

$\mathrm{Y}=\mathrm{a}+\mathrm{b}_{1} \mathrm{~F}+\mathrm{b}_{2} \mathrm{X}+\mathrm{b}_{3} \mathrm{~T}+\mathrm{u}_{1}$

$\mathrm{F}=\mathrm{a}+\mathrm{c}_{1} \mathrm{Y}+\mathrm{c}_{2} \mathrm{~T}+\mathrm{c}_{3} \mathrm{CR}+\mathrm{u}_{2}$

In the regressions, (1) and (2), we expect a positive sign of each of the three coefficients, $b_{1}, b_{2}$, and $b_{3}$ and they are to be statistically significant to support our "theory". Export-led growth hypothesis has been a popular one in the development economics literature for a long time. The "Asian Tigers" have been supposed to roar and thrive on exports and to have made the most of the spill over effects. There are supposed to be static and dynamic effects of participation in international trade; static benefits emanate from specialisation in products in which the country has comparative advantages, leading to a better allocation of resources; dynamic gains are said to emanate from increased competition, $R \& D$ to improve techniques, flow of information on new methods and products, and so on (Jones and Sakong, 1980; Michell, 1982; Krueger, 1985; Linder, 1986; Kim, 1988; World Bank, 1993; Little, 1994; Rodrik, 1995, Ghatak, 1998). However, such positive effects of exports on economic growth are to be treated as testable hypotheses and not be taken for granted (Rodrik, 1995). Net effects of FDI may not always be positive and after excluding effects of FDI on imports or import content of exports from foreign companies. The data on imports of parts or accessories of electronics and automobiles have too many missing entries in the data set; so we could not use this variable.

The data on the number of telephone lines, per thousand inhabitants, $\mathrm{T}$, are available for all 140 countries; this is an important variable in filtering information 
through to the whole country and a free flow of information is important for economic growth. Channelling information is not always smooth in the developing countries, especially in Africa, Asia, and a few other regions for the fear of its abuse by the speculators, or other profiteers for non-developmental purposes; so, information is not always released in good time; however, the number of telephone lines can act as a catch-all independent variable and may not be unduly affected by various restrictive policies practised by the government or policy makers in some developing countries.

In addition, we have estimated a number of auxiliary regressions and correlation between the independent variables in the above equations. For instance, the simple regression equations are:

$$
\begin{aligned}
& F=a+c g+u \\
& F=a+c Y+u \\
& F=a+c T+u \\
& X=a+b F+u \\
& g=a+b_{1} F+u \\
& Y=a+b_{1} F+u \\
& g=a+b_{2} X+u \\
& Y=a+b_{2} X+u \\
& g=a+b_{3} T+u \\
& Y=a+b_{3} T+u \\
& F=a+C R+u
\end{aligned}
$$

The auxiliary regressions (4i) to (4xi) will each serve a useful purpose. The first equation (4i) indicates how much the rate of growth of the host country determines the amount of FDI; the equation (4ii) will indicate how real per-capita income of each host country influences FDI. This has important consequences for least-squares (OLS) estimations of (1) and (2), namely, the simultaneous-equation bias. The explanatory variable, F, being dependent on $g$ and $\mathrm{Y}$, in the respective models, F will be correlated with the error term, $u$, in (1) and (2).Under such circumstances, we should estimate the main equations (1) and (2) by an SEM, such as the instrumental variable method (IVM). An instrumental variable should be such that it is correlated with the explanatory variable in question but it should be independent of the error term in the main equation. In the cross-country data at hand, the only instrumental variable we can find is country risk rating. Our equation (4xi) will show how the country risks rating, affects FDI. If it affects FDI positively, the IV estimate of $b_{1}$, will be a consistent estimate free of the simultaneous equation bias. The advantage of using country risk as an instrument is that it can be assumed independent of the variables, export to GDP ratio and the number of telephone lines per thousand populations, and of course, the error term in equation (1) and (2). The condition for applying IVM or any other SEM is that the equations of the model should be identified. The issue of identification will be discussed in the next section in more detail. For now, it will suffice to comment that (1) and (2) are identified.

The auxiliary equation (4iv) will indicate the extent of multicollinearity in the main regressions (1) and (2). The usual symptom of multicollinearity is large standard error and low $\mathrm{t}$-value of the coefficient in question, the coefficient of $\mathrm{X}$ in this context. If the extent of multicollinearity is high, then the strength of influence of FDI on real per-capita income or growth rate can not be determined precisely. Equations (4v)-(4ix) will, in the event of high multicollinearity, just indicate broadly 
the dependence of growth and real per-capita GDP on FDI. However, the estimates of coefficient of $F$ will be interpreted as omitted variable estimate (OVE); OVE has a smaller variance than the OLS estimate but OVE has a positive bias; such omitted variable bias, however, can change the sign of the respective coefficient from what is to be expected (Maddala, 2001, pp. 160-161). For time-series data, fully modified OLS method is also recommended to take account of endogeneity of explanatory variables (Phillips and Hansen, 1990).

In all cross-country regressions, one has to watch out for heteroscedasticity. Countries included in the same regression may have their specific characteristics, which mean that the random disturbance variable will not have a constant variance but such variance will change with explanatory variables; most of the usual tests of heteroscedasticity, therefore, use regressions of residuals squared, on the main explanatory variable and test if this coefficient is statistically significant. In crosscountry data, it is likely that the extent of serial correlation as measured by the Durbin Watson statistic (DW) will be insignificant because random disturbance in one country may not affect the random disturbance in another country, unless it is the host country and the foreign country investing in the former. More comments will be added on each of these issues with reference to the derived estimates in the following section.

\section{Data and Variables}

We use the cross country data for 140 countries to assess effects of FDI on macro variables important for economic growth. The time period over which data on growth of real GDP are averaged is the decade, 1991-2001. The data on inward FDI in stock, F, and real per-capita GDP, Y, are averaged for the two years, 1999-2001. We consider real GDP growth, $g$; real per-capita GDP, Y, the exports to GDP ratio, X; composite risk rating in country, $\mathrm{CR}$, and number of telephone mainlines per thousand inhabitants, T. The data on per-capita real GDP, GDP growth, foreign direct investment in stock, and the number of telephone mainlines are available for all one hundred and forty countries included in the sample. The data on other variables, for example, $\mathrm{X}$ are missing for Brunei Darussalam, the serial number of which is eighteen; the data on research and development expenditure and those on import to GDP ratio are missing for many countries; so we had to exclude some of these variables from our regression analysis. Data on country risk rating were missing for many countries. Still we used the variable for various estimations of single and simultaneous equation models. All the data used in our study have been obtained from UN (2003). We have also used scores of growth rate, gs, scores of real GDP, Ys, and scores of FDI, Fs, in some regressions. The scores of each variable are derived in the UN data (UN, 2003) within the range, 0 to 1 , taking the country with the highest value of each variable as the numeraire for respective scores. For calculating scores of real GDP growth, China is taken as the numeraire, for GDP percapita scores, Norway is taken as the numeraire, and for scores of percentage FDI, US FDI is taken as the base equal to 1. For example, the US inward FDI in stock, averaged for 1999-2001, as percentage of world total is $19.48=1$; therefore, the score of inward FDI in stock for the UK in the same period, is obtained as 7.66/19.48 = 0.39 ; similarly for the growth rate and real per-capita GDP scores. For composite risk rating, Switzerland has been used as the numeraire. 


\section{Interpretations of Regression Estimates}

In Table 1, the results of all auxiliary regressions and the correlation between them are presented respectively in the two parts. The results in part A of Table 1 suggest that the growth rate of the host country does not influence FDI at all; in part B, the correlation between them is also statistically insignificant. Similarly, the exports to GDP ratio do not get significantly affected by FDI either and the correlation coefficient between exports-GDP ratio and FDI is also statistically insignificant for all the countries. Exports data were not available for Brunei Darussalam. The results in Parts A and B of Table 1 show significant positive effects of real per-capita income and the number of telephone mainlines available per thousand inhabitants on the amount of FDI. The correlations are also statistically significant for these two pairs. So, the results support the view that the income of the host country is an important factor determining FDI and so is the infrastructure of telecommunications. It is understandable that without a good infrastructure of telecommunications, the foreign companies, or the domestic companies for that matter, would find it extremely difficult to function or even start up. This raises the issue of estimation by IVM, using country risk rating, $\mathrm{CR}$, as the instrument. The data on $\mathrm{CR}$ are available with a lot of discontinuity and it is indicated by the serial number of countries in part B of Table 2.

The main estimates reported in Table 2 suggest that none of the growth rate regressions yield good results. The adjusted $\mathrm{R}^{2}$ is negative in all cases except in the IVM and only the constant term is statistically significant. One explanatory reason may be that the growth rate of real per-capita GDP has been averaged over the entire decade of the nineties and the other variables are averaged over the two years, 19992001. The results are of the same type in case of regressions of scores of growth rates. The other results of main OLS regressions in Table 2 suggest that the stock of inward FDI is statistically significant at the 5\% level in all the regressions of real per-capita GDP and in all the regressions of scores of real GDP. The number of telephone mainlines is statistically significant in all regressions. The coefficient of percentage of exports to GDP is statistically significant in all regressions but in the regression of the first seventeen countries. The splitting of data was necessary because the data for some countries were not available except for GDP, FDI, and number of telephone main lines.

To apply the IVM, we first check on identification of the equations of each model. Both equations of the model (1) and (3i) and the model (2) and (3ii) are exactly identified by the order and the rank condition ${ }^{2}$. The instrumental variable estimates are given in Table 4 for data of various sample sizes. We only report the ones which show statistical significance of FDI.

The generalised IV estimates of the coefficients of FDI are statistically significant in growth rate regressions for countries serially numbered as 15-43. The IV estimates of coefficients of number of telephone mainline and country risk rating are also statistically significant; but the negative sign of coefficient of telephone lines can not be justified. The adjusted $\mathrm{R}^{2}$ in simultaneous equation method is not the same as in the case of single equation estimation; therefore, it is customary to report the adjusted generalised $\mathrm{R}^{2}$ known as GR-Bar square as a broad indication of goodness of fit (Desai, 1976). The adjusted GR-Bar square is positive in all the IV regressions of the growth rate, which is a significant improvement in the performance of the growth rate regression. The contribution of FDI to real per-capita GDP assessed by the IVM are reported in Part B of Table, 3. The FDI is statistically significant in explaining real 
per-capita GDP in countries numbered as 123-134. Its coefficient was positive in the real per-capita GDP regressions in all cases. Significance of the number of telephone mainlines is retained in the real per-capita GDP regressions as well. The GR Bar square in the real per-capita GDP regressions is very high $(0.91)$ in the countries, numbered 123-134.

The DW statistics are all above the upper limit of the critical value at the $5 \%$ level for all the single-equation and the simultaneous-equation estimations meaning there is no evidence of serial correlation in the data, as expected. The smallest DW obtained is 1.58 for country numbers, 106-120, and the 5\% critical value for the upper limit of DW for 15 observations, is 1.54 . Some evidence of heteroscedasticity is found in the data as shown by the chi-square given in Tables 1 and 2, although not all of them are statistically significant.

It is however difficult to compare our IV estimate of impact of FDI with the OLS estimate for having split samples.

\section{Conclusions}

In the cross-country data for one hundred and forty countries, we find a positive and significant impact of inward FDI in stock on real per-capita GDP in the OLS single-equation estimate. The IV estimate of the coefficient of FDI is positive and statistically significant at the 5\% level in countries numbered 123-134. In this group of countries are included the ones with the first letter of the names as "T" to "U" 3 . The OLS estimation of growth rate regressions generate poor results; but the IV estimate of FDI is positive and statistically significant in countries 15-43. The serial numbers, $15-43$ are for countries, with the first letter of names, "B" to "G"3 . In either group are mixed countries with high rates of growth, a large amount of FDI, and so on with low growth, a small amount of FDI. For instance the USA, the UK, and Uganda and the United Republic of Tanzania are in the same group; similarly in the other lot, for growth rate regressions, China with a rate of $9.7 \%$ is mixed with Congo Democratic Republic with a negative average growth rate of $-4.3 \%$. This is a good characteristic in the data set; the outliers of both kinds are balanced; as a result these SEM estimates are statistically significant. The instrument used is the country risk rating, which is correlated with FDI and correlation is statistically significant in four out of seven cases. In an aggregative approach adopted in our paper, important detail is not obtainable. The IV estimates being for split samples go some way in indicating the wide disparity in the performance of FDI in the countries included in the data. The highest percentage of inward FDI in stock is shown in the United States and this is 19.48; next two countries are the UK with $7.66 \%$ and Iceland with $7.14 \%$. The highest per-capita GDP during 1999-2001 is recorded for Norway and the amount, \$36399.2 is taken as the numeraire for calculating scores of GDP per-capita; however, the percentage of inward FDI in stock as a percentage of world total is only 0.51 , which is very low. The features like this, while reducing multicollinearity between the variables, $\mathrm{Y}$ and $\mathrm{F}$, in the single-equation OLS estimate, will also make SEM IV estimate less meaningful. Therefore, all the SEM IV estimates of effect of FDI on rate of growth are not statistically significant; whereas, the effect of FDI on real percapita GDP is positive but insignificant. 
6 Empirical Results ${ }^{4}$

Table 1 Auxiliary Regressions

\begin{tabular}{|c|c|c|c|c|c|c|c|}
\hline \multicolumn{8}{|c|}{ Part A Main Results of Auxiliary Regressions } \\
\hline Regression and Serial number of countries & Constant & t-ratio & Slope & t-ratio & $\bar{R}^{2}$ & DW & $\chi_{H}^{2}$ \\
\hline $\begin{array}{l}\mathrm{F}=\mathrm{a}+\mathrm{c}_{1} \mathrm{~g} \\
\text { Countries } 1-140\end{array}$ & $0.51796^{*}$ & 2.0222 & 0.06267 & 0.98373 & -0.002 & 2.14 & 0.10 \\
\hline $\begin{array}{l}\mathrm{F}=\mathrm{a}+\mathrm{c}_{2} \mathrm{Y} \\
\text { Countries 1-140 }\end{array}$ & -0.04402 & 0.2777 & $0.0001 *$ & 6.7597 & 0.243 & 2.06 & $23.94 *$ \\
\hline $\begin{array}{l}\mathrm{F}=\mathrm{a}+\mathrm{c}_{3} \mathrm{~T} \\
\text { Countries } 1-140\end{array}$ & -0.2093 & 0.9468 & 0.0043 & 5.8838 & 0.194 & 2.07 & $11.83 *$ \\
\hline $\begin{array}{l}X=a+b F \\
\text { Countries 1-17 } \\
\text { Countries 19-140 }\end{array}$ & $\begin{array}{l}41.0103 * \\
41.1458 *\end{array}$ & $\begin{array}{l}5.330 \\
16.94\end{array}$ & $\begin{array}{l}-0.3089 \\
0.29509\end{array}$ & $\begin{array}{l}0.4979 \\
0.2795\end{array}$ & $\begin{array}{l}-0.660 \\
-0.007\end{array}$ & $\begin{array}{l}2.20 \\
2.13\end{array}$ & $\begin{array}{l}3.11 \\
3.98^{*}\end{array}$ \\
\hline $\begin{array}{l}\mathrm{F}=\mathrm{a}+\mathrm{bCR} \\
\text { Countries 1-13 } \\
\text { Countries 15-43 } \\
\text { Countries 45-68 } \\
\text { Countries 70-85 } \\
\text { Countries 87-104 } \\
\text { Countries 106-120 } \\
\text { Countries 123-134 }\end{array}$ & $\begin{array}{l}-3.0273 \\
-1.9138 \\
-6.2860^{*} \\
-0.8296 \\
-2.6370 \\
-2.4388^{*} \\
-13.6454\end{array}$ & $\begin{array}{l}2.1396 \\
0.9612 \\
2.3029 \\
0.7349 \\
1.9570 \\
2.7194 \\
1.2326\end{array}$ & $\begin{array}{l}0.0517^{*} \\
0.0369^{*} \\
0.0999^{*} \\
-0.0149 \\
0.0434^{*} \\
0.0421^{*} \\
0.2298\end{array}$ & $\begin{array}{l}2.5653 \\
2.3324 \\
2.6534 \\
0.9027 \\
2.2890 \\
3.4417 \\
1.4615\end{array}$ & $\begin{array}{l}0.317 \\
0.026 \\
0.208 \\
-0.012 \\
0.199 \\
0.208 \\
0.093\end{array}$ & $\begin{array}{l}1.25 \\
2.27 \\
1.57 \\
2.24 \\
1.41 \\
1.57 \\
2.21\end{array}$ & $\begin{array}{l}8.45^{*} \\
0.51 \\
5.28^{*} \\
0.27 \\
5.03 \\
5.28^{*} \\
1.52\end{array}$ \\
\hline $\begin{array}{l}\mathrm{Y}=\mathrm{a}+\mathrm{bT} \\
\text { Countries 1-140 }\end{array}$ & $-1366.1^{*}$ & 2.5800 & $38.50^{*}$ & 21.7900 & 0.770 & 2.24 & $22.72 *$ \\
\hline $\begin{array}{l}g=a+b T \\
\text { Countries } 1-140\end{array}$ & $2.8852 *$ & 8.7000 & 0.0001 & 0.1290 & -0.007 & 1.95 & 2.57 \\
\hline $\begin{array}{l}g=a+b X \\
\text { Countries } 1-17 \\
\text { Countries } 19-140\end{array}$ & $\begin{array}{l}3.4200^{*} \\
2.6600^{*}\end{array}$ & $\begin{array}{l}3.5000 \\
5.3300\end{array}$ & $\begin{array}{l}-0.0120 \\
0.0060\end{array}$ & $\begin{array}{l}0.6100 \\
0.6100\end{array}$ & $\begin{array}{l}-0.040 \\
-0.005\end{array}$ & $\begin{array}{l}1.89 \\
1.94\end{array}$ & $\begin{array}{l}0.02 \\
0.62\end{array}$ \\
\hline $\begin{array}{l}Y=a+b X \\
\text { Countries 1-17 } \\
\text { Countries 19-140 }\end{array}$ & $\begin{array}{l}2161.1^{*} \\
3851.4^{*}\end{array}$ & $\begin{array}{l}0.5640 \\
2.3600\end{array}$ & $\begin{array}{l}114.945 \\
66.5100\end{array}$ & $\begin{array}{l}1.4490 \\
1.9700\end{array}$ & $\begin{array}{l}0.064 \\
0.023\end{array}$ & $\begin{array}{l}2.05 \\
1.89\end{array}$ & $\begin{array}{l}0.77 \\
0.12\end{array}$ \\
\hline $\begin{array}{l}g=a+b F \\
\text { Countries } 1-140\end{array}$ & $2.8400^{*}$ & 11.4900 & 0.1100 & 0.9800 & -0.003 & 1.96 & 0.35 \\
\hline $\begin{array}{l}\mathrm{Y}=\mathrm{a}+\mathrm{bF} \\
\text { Countries } 1-140\end{array}$ & $5119.1^{*}$ & 7.0300 & $2246.7 *$ & 6.7600 & 0.240 & 1.87 & 1.59 \\
\hline
\end{tabular}

Part B Linear Correlation Between Pairs of Variables

\begin{tabular}{ccc}
\hline Variables and Serial number of countries & Estimated correlation coefficient & Critical value at the 5\% level \\
\hline g, F & & \\
$1-140$ & 0.0834 & 0.195 \\
X, F & 0.0255 & 0.195 \\
19,140 & 0.01 & 0.482 \\
$1-17$ & & \\
T, F & $0.2005^{*}$ & 0.195 \\
1,140 & & \\
Y, F & $0.2487^{*}$ & 0.195 \\
1,140 &
\end{tabular}

Notes. t-ratios are in absolute values. * implies statistical significance at $5 \% . \chi_{H}^{2}$ stands for heteroscedasticity. 
Table 2 OLS Results

\begin{tabular}{|c|c|c|c|c|c|c|c|}
\hline \multirow{2}{*}{ Regression and Serial number of countries } & \multicolumn{7}{|c|}{ Part A Main Results of the OLS Regressions } \\
\hline & a & $\mathrm{b}_{1}$ & $\mathrm{~b}_{2}$ & $\mathrm{~b}_{3}$ & $\bar{R}^{2}$ & DW & $\chi_{H}^{2}$ \\
\hline $\begin{array}{l}g=a+b_{1} F+b_{2} X+b_{3} T s \\
\text { Countries } 1-140\end{array}$ & $\begin{array}{l}3.4968 * \\
(3.1967)\end{array}$ & $\begin{array}{l}0.266 \\
(0.4027)\end{array}$ & $\begin{array}{l}-0.006 \\
(0.2606)\end{array}$ & $\begin{array}{l}-0.0024 \\
(0.6099)\end{array}$ & -0.6711 & 2.10 & 1.93 \\
\hline \multicolumn{8}{|l|}{$g s=a+b_{1} F s+b_{2} X s+b_{3} T s$} \\
\hline Countries $1-17$ & $\begin{array}{l}0.6287 * \\
(10.64)\end{array}$ & $\begin{array}{l}0.30 \\
(0.396)\end{array}$ & $\begin{array}{l}-0.057 \\
(0.024)\end{array}$ & $\begin{array}{l}-0.106 \\
(0.617)\end{array}$ & -0.1676 & 2.09 & 0.71 \\
\hline Countries $19-140$ & $\begin{array}{l}0.5835 \\
(20.94)\end{array}$ & $\begin{array}{l}0.30 \\
(0.1526)\end{array}$ & $\begin{array}{l}-0.057 \\
(0.0755)\end{array}$ & $\begin{array}{l}-0.106 \\
(0.0209)\end{array}$ & -0.013 & 1.96 & 0.13 \\
\hline $\begin{array}{l}g s=a+b_{1} F s+b_{2} T s \\
\text { Countries } 1-140\end{array}$ & $\begin{array}{l}0.5985^{*} \\
(30.8401)\end{array}$ & $\begin{array}{l}0.1516 \\
(1.0382)\end{array}$ & $\begin{array}{l}-0.019 \\
(0.3727)\end{array}$ & & -0.066 & 1.97 & 0.01 \\
\hline \multicolumn{8}{|l|}{$\mathrm{Y}=\mathrm{a}+\mathrm{b}_{1} \mathrm{~F}+\mathrm{b}_{2} \mathrm{X}$} \\
\hline Countries $1-17$ & $\begin{array}{l}-346.481 \\
(0.9979)\end{array}$ & $\begin{array}{l}3885.5 \\
(2.3147)\end{array}$ & $\begin{array}{l}117.023 \\
(1.6753)\end{array}$ & & 0.2749 & 1.55 & 0.03 \\
\hline Countries $19-140$ & $\begin{array}{l}-2482.9 \\
(1.7459)\end{array}$ & $\begin{array}{l}2186.9 * \\
(6.5123)\end{array}$ & $\begin{array}{l}61.6889 * \\
(2.1254)\end{array}$ & & 0.2749 & 1.89 & 0.27 \\
\hline \multicolumn{8}{|l|}{$Y s=a+b_{1} F s+b_{2} X s$} \\
\hline Countries $1-140$ & $\begin{array}{l}0.0734 * \\
(2.2974)\end{array}$ & $\begin{array}{l}1.1994^{*} \\
(6.8116)\end{array}$ & $\begin{array}{l}-0.2942 * \\
(2.4090)\end{array}$ & & 0.26864 & 1.88 & 0.50 \\
\hline \multicolumn{8}{|l|}{$\mathrm{Ys}=\mathrm{a}+\mathrm{b}_{1} \mathrm{~F}+\mathrm{b}_{2} \mathrm{~T}$} \\
\hline Countries $1-140$ & $\begin{array}{l}-1242.8^{*} \\
(2.4102)\end{array}$ & $\begin{array}{l}588.976^{*} \\
(2.9760)\end{array}$ & $\begin{array}{l}359429 * \\
(18.7036)\end{array}$ & & 0.7855 & 2.23 & $10.52 *$ \\
\hline \multicolumn{8}{|l|}{$Y_{s}=a+b_{1} F+b_{2} X+b_{3} T$} \\
\hline Countries $19-140$ & $\begin{array}{l}846.8415 \\
(1.0529)\end{array}$ & $\begin{array}{l}628.5687 \\
(3.0465)\end{array}$ & $\begin{array}{l}-11.9651 \\
(0.725)\end{array}$ & $\begin{array}{l}35.675^{*} \\
(16.6871)\end{array}$ & 0.78208 & 2.11 & $9.42 *$ \\
\hline Countries $1-17$ & $\begin{array}{l}-1781.3 \\
(1.0632)\end{array}$ & $\begin{array}{l}-628.947 \\
(0.6209)\end{array}$ & $\begin{array}{l}5.881 \\
(0.16177)\end{array}$ & $\begin{array}{l}43.5585^{*} \\
(7.12023) \\
\end{array}$ & 0.8399 & 2.29 & $6.99 *$ \\
\hline
\end{tabular}

Part B Estimates of Linear Correlation Coefficient between Country Risk and Inward FDI

\begin{tabular}{lcc}
\hline Serial Number of Countries & Estimated correlation coefficient & Critical value at the 5\% level \\
\hline $1-13$ & $0.61118^{*}$ & 0.532 \\
$15-43$ & 0.2483 & 0.367 \\
$45-68$ & $0.4922^{*}$ & 0.404 \\
$70-85$ & 0.2345 & 0.497 \\
$87-104$ & $0.4968^{*}$ & 0.468 \\
$106-120$ & $0.690^{*}$ & 0.514 \\
$123-134$ & 0.4195 & 0.576 \\
\hline Notes: t-ratios are in absolute values and parentheses. * implies statistical significance at 5\%. $\chi_{H}^{2}$ stands for heteroscedasticity.
\end{tabular}


Table 3 Generalised Instrumental Variable Estimates of Equations

\begin{tabular}{|c|c|c|c|c|c|c|c|}
\hline Regression & $\mathrm{a}$ & $\mathrm{b}_{1}$ or $\mathrm{c}_{1}$ & $b_{2}$ or $c_{2}$ & $\mathrm{~b}_{3}$ or $\mathrm{c}_{3}$ & $\mathrm{~b}_{4}$ or $\mathrm{c}_{4}$ & $G R-R^{2}$ & DW \\
\hline \multicolumn{8}{|l|}{ Panel A: Serial Number 15-43 } \\
\hline$g=a+b_{1} F+b_{2} X+b_{3} T+b_{4} C R$ & $\begin{array}{l}-9.35 \\
(2.41)\end{array}$ & $\begin{array}{l}0.59^{*} \\
(2.10)\end{array}$ & $\begin{array}{l}-0.005 \\
(0.28)\end{array}$ & $\begin{array}{l}-0.008 * \\
(3.15)\end{array}$ & $\begin{array}{l}0.201 * \\
(3.37)\end{array}$ & 0.318 & 1.73 \\
\hline $\mathrm{F}=\mathrm{a}+\mathrm{c}_{1} \mathrm{~g}+\mathrm{c}_{2} \mathrm{~T}+\mathrm{c}_{3} \mathrm{CR}+\mathrm{c}_{4} \mathrm{X}$ & $\begin{array}{l}3.03 \\
(10.64)\end{array}$ & $\begin{array}{l}0.263^{*} \\
(0.396)\end{array}$ & $\begin{array}{l}-0.04 * \\
(0.024)\end{array}$ & $\begin{array}{l}-0.05 \\
(0.617)\end{array}$ & -0.03 & 0.18 & 2.17 \\
\hline \multicolumn{8}{|l|}{ Panel B: Serial Number 123-134 } \\
\hline$Y=a+b_{1} F+b_{2} X+b_{3} T+b_{4} C R$ & $\begin{array}{l}-16994 * \\
(2.17)\end{array}$ & $\begin{array}{l}695.9 * \\
(2.09)\end{array}$ & $\begin{array}{l}-24.36 \\
(0.38)\end{array}$ & $\begin{array}{l}25.48 * \\
(3.02)\end{array}$ & $\begin{array}{l}262.88 * \\
(1.93)\end{array}$ & 0.91 & 2.67 \\
\hline $\mathrm{F}=\mathrm{a}+\mathrm{c}_{1} \mathrm{Y}+\mathrm{c}_{2} \mathrm{~T}+\mathrm{c}_{3} \mathrm{CR}+\mathrm{c}_{4} \mathrm{X}$ & $\begin{array}{l}7.05 \\
(0.82) \\
\end{array}$ & $\begin{array}{l}0.0005^{*} \\
(2.09)\end{array}$ & $\begin{array}{l}-0.003 \\
(0.29) \\
\end{array}$ & $\begin{array}{l}-0.05 \\
(0.14) \\
\end{array}$ & $\begin{array}{l}-0.09 \\
(0.94) \\
\end{array}$ & 0.74 & 2.26 \\
\hline
\end{tabular}

Note: The absolute value of t-ratios is in parentheses, * implies statistical significance at $5 \%$. 


\section{References}

Alfaro, L. Chanda, A. Kalemli-Ozcan, S., and Sayek, S. (2004), "FDI and economic growth: the role of local financial markets", Journal of International Economics, Vol.64, No.1, pp. 89-112.

Balasubramanyan, V. N., Salisu, M. And Sapsford, D. (1996), "Foreign direct investment and growth in EP countries and IP countries", The Economic Journal, Vol.106, No.1, pp.92-105.

Bertheleray, J. C. and Demurger, S. (2000), “FDI and economic growth: theory and application to China", Review of Development Economics, Vol.4, No.2, pp.140-155

Bengoa, M. and Sanchez-Robles, B. (2003), "Foreign direct investment, economic freedom and growth: new evidence from Latin America", European Journal of Political Economy, Vol.19, No.3, pp.529-543.

Biswas, R., (2002), "Determinants of foreign direct investment", Review of Development Economics, Vol.6, No.3, pp.492-504.

Blomstrom, M. (1986). "Foreign investment and productive efficiency: the case of Mexico," Journal of Industrial Economics, Vol. 35, No.1, pp.97-110.

Bruno, M. and Easterly, W. (1998), "Inflation crises and long-run growth”, Journal of Monetary Economics, Vol.41, No.1, pp.3-26

Borensztein, E., De Gregorio, J. And Lee, W. (1998), "How does foreign direct investment affect economic growth?" Journal of International Economics, Vol.45, No.1, pp.115-135.

De Mello, L.R., (1997), "FDI in developing countries and growth; a selective survey", Journal of Development Studies, Vol. 34, No.2, pp.1-34.

Casson, M. (1986), (ed.) Multinationals and World Trade, London, George Allen and Unwin.

Caves, R.E. (1971), "International corporations: the industrial economics of foreign investment”, Economica, Vol.38, No.149, pp.1-27.

Desai, M. (1976), Applied Econometrics, London, Philip Alan.

Dunning, J.H. (1993), Multinational Enterprises and Global economy, Wokingham, Addison-Wesley

De Gregorio, (1992), "Economic growth in Latin America”, Journal of Development Economics, Vol.39, No.3, pp.59-84.

Ghatak, A. (1998), "Vector autoregression modelling and forecasting growth of South Korea", Journal of Applied Statistics, Vol.25, No.5, pp. 579-592.

Grossman, G. and Helpman, E. (1991) Innovation and Growth in the Global Economy, MIT press, Cambridge, MA.

Gupta, V.K. (1983), "A simultaneous determination of structure, conduct and performance in Canadian manufacturing", Oxford Economic Papers, Vol.35, No.2, pp.579-592.

Halicioglu, F. (2001), "An econometric analysis of foreign direct Investment flows into Turkey from the major global regions: 1975-1999" International Conference in Economics V, Economics Research Centre, Middle East Technical University, Ankara, Turkey.

Hufbauer, G.C. (1975), "The multinational corporation and direct investment", in Kenen, P.B. (ed.) International Trade and Finance: Frontiers of Research, Cambridge, Cambridge University Press. 
Jones, J. and Sakong, J. (1980), Government Business and Entrepreneurship in Economic Development: The Korean Case, Cambridge, MA, Harvard University Press.

Kim, K. (1988), "Korea in the 1990s:making the transition to a developed economy", World Development, Vol.16, No.1, pp.7-18.

Kindleberger, C.P. (1969), American Business Abroad: Six Lectures on Direct Investment, New Haven, Yale University Press.

Krueger, A. (1985), "The Experience and lessons of Asia's super exporters", in Corbo, V., et.al., (Eds), Export Oriented Development Strategies: The Success of Five Newly Industrialised Countries London, West view.

Kumar, N. (1987), "Intangible assets, internalisation and foreign production: direct investment and licensing in Indian manufacturing" Weltwirtschaftliches Archiv, Vol.123, No.1, pp.325-345.

Lall, S. (1980), The Multinational Corporations: Nine Essays, London, The Macmillan Press.

Lim, E. G., (2001), " Determinants of, and the relation between, foreign direct investment and growth; a summary of the recent literature", IMF Working Papers, No: WP/01/175.

Linder, S.B., (1986), The Pacific Century, Stanford, CA, Stanford University Press.

Little, I.M.D. (1994), Trade and Industrialisation Revisited, Oxford, Nuffield College.

Liu, T.C. (1960), "Underidentification, structural estimation, and forecasting", Econometrica, Vol.28, No.4, pp.855-865.

Maddala, G.S. (2001), Introduction to Econometrics, New York, John Wiley

Michell, T. (1982), South Korea: visions of the future for labour surplus economies? In: Bienfield, M. and Godfre,M. (Eds.), The Struggle for Development: The Natioantal Startegies in an International Context, London, Wiley.

Pesaran, M.H. and Pesaran, B. (1997), Microfit 4.0: Windows Version, Oxford, Oxford University Press

Phillips, P.C.B. and Hansen, B.E. (1990), "Statistical inference in instrumental variables regression with I(1) processes", The Review of Economic Studies, Vol.57, No1, pp.99-125.

Rodrik, D. (1995), "Getting interventions right: how South Korea and Taiwan grew rich", Economic Policy, Vol.20, No.2, pp. 55-97.

Romer, P. (1990), "Endogenous technological change", Journal of Political Economy, Vol. 98, No.2, pp.71-102.

Root, F.R. , and Ahmet, A.A. (1979), "Empirical determinants of manufacturing direct foreign investment in developing countries, Economic Development and Cultural Change, Vol.27, No.4, pp.751-767.

Rueber, G.L. (1973), Private Foreign Investment in Development, Oxford, Clarendon Press.

Saunders, R.S. (1982), "The determinants of inter-industry variation of foreign ownership in Canadian manufacturing", Canadian Journal of Economics, Vol.15, No.1, pp.77-84.

Sims, C. A. (1980), "Macroeconomics and reality", Econometrica ,Vol. 48, No.1, pp.1-48.

Sahoo, D. and Mathiyazhagan, M. I. (2003). " Economic growth in India: does FDI inflow matter?", The Singapore Economic Review, Vol.48, No.2, pp.151-171. 
Slywester, K. (2005), "Foreign direct investment, growth and income equality in less developed countries", International Review of Applied Economics, Vol.19, No.3, pp.289-300.

United Nations (2003), World Investment Report: FDI Policies for Development: National and International Perspectives, New York and Geneva, United Nations.

World Bank (1993), The East Asian Miracle: Economic growth and Public Policy, Oxford, Oxford University Press

Zhiang, K.H. (2001), "Does FDI promote economic growth evidence from east Asia and Latin America" Contemporary Economic Policy, Vol.19, No.2, pp.175-185.

\section{Notes}

1. For R\&D expenditure, data are not available for a 57 countries including Albania, Algeria, Angola, and so on. Relevant regressions have been adjusted for the missing data.

2. By the order condition, (4i) excludes the variable, $\mathrm{CR}$ and is, therefore, just identified; the equation (4ii) excludes $\mathrm{X}$ and, is therefore, just identified. By the rank condition, the matrix for (4i) is (c3) and for (4ii), it is (b2). Therefore, both equations are identified by the rank condition if $\mathrm{c} 3$ and $\mathrm{b} 2$ turn out to be non-zero and statistically significant.

3. The countries included in 123-134 are Thailand, Togo, Trinidad and Tobago, Tunisia, Turkey, Uganda, Ukraine, United Arab Emirates, United Kingdom, United Republic of Tanzania, United States and Uruguay. The countries included in the serial numbers, 15-43 are Bolivia, Botswana, Brazil, Brunei Darussalam, Bulgaria, Burkina Faso, Cameroon, Canada, Chile, China, Colombia, Congo, Congo Democratic Republic, Costa Rica, Cote d'Ivoire, Croatia, Cyprus, Czech Republic, Denmark, Dominican Republic, Ecuador, Egypt, El Salvador, Estonia, Ethiopia, Finland, France, Gabon, Gambia and Georgia.

4. Econometric estimations are implemented with Microfit 4 of Pesaran and Pesaran (1997). 